\title{
The Legal Effects of EU Competition Soft Law in the Decisions of National Competition Authorities
}

Citation for published version (APA):

Stähler, L., \& Eliantonio, M. (2020). The Legal Effects of EU Competition Soft Law in the Decisions of National Competition Authorities: The Case of the Bundeskartellamt. European Competition and Regulatory Law Review, 4(4), 273-288. https://doi.org/10.21552/core/2020/4/5

Document status and date:

Published: 01/10/2020

DOI:

10.21552/core/2020/4/5

Document Version:

Publisher's PDF, also known as Version of record

Document license:

Taverne

\section{Please check the document version of this publication:}

- A submitted manuscript is the version of the article upon submission and before peer-review. There can be important differences between the submitted version and the official published version of record.

People interested in the research are advised to contact the author for the final version of the publication, or visit the DOI to the publisher's website.

- The final author version and the galley proof are versions of the publication after peer review.

- The final published version features the final layout of the paper including the volume, issue and page numbers.

Link to publication

\footnotetext{
General rights rights.

- You may freely distribute the URL identifying the publication in the public portal. please follow below link for the End User Agreement:

www.umlib.nl/taverne-license

Take down policy

If you believe that this document breaches copyright please contact us at:

repository@maastrichtuniversity.nl

providing details and we will investigate your claim.
}

Copyright and moral rights for the publications made accessible in the public portal are retained by the authors and/or other copyright owners and it is a condition of accessing publications that users recognise and abide by the legal requirements associated with these

- Users may download and print one copy of any publication from the public portal for the purpose of private study or research.

- You may not further distribute the material or use it for any profit-making activity or commercial gain

If the publication is distributed under the terms of Article $25 \mathrm{fa}$ of the Dutch Copyright Act, indicated by the "Taverne" license above, 


\title{
The Legal Effects of EU Competition Soft Law in the Decisions of National Competition Authorities:
}

\author{
The Case of the Bundeskartellamt
}

\author{
Leander Stähler and Mariolina Eliantonio*
}

Soft law issued by the European Commission plays an important role in the area of EU competition law. Focusing on the legal effect of competition soft law as applied by Germany's national competition authority, the Bundeskartellamt, this contribution analyses how the authority pursues interpretational and decisional objectives through references to competition soft law. This contribution quantifies the references made to soft law and categorises these references on the basis of the involvement of other sources of law in an individual reference. It is shown that the Bundeskartellamt is comfortable making reference to competition soft law as the sole legal basis for certain parts of many decisions, ascribing to competition soft law a strong legal effect in several instances.

Keywords: EU soft law; enforcement; Bundeskartellamt; NCAs; EU Commission

\section{Introduction}

Effective as of May 2004, Regulation $1 / 2003^{1}$ on the Implementation of the Rules on Competition significantly reconfigured competition enforcement in the EU, by entrusting national authorities to enforce both European and national competition rules. As a consequence, the need for cooperation between the Commission and national competition authorities (NCAs) has become a key issue for the decentralised enforcement of competition rules. To this end, the Commis- sion has, amongst others, issued a number of soft law measures aimed specifically at ensuring a coherent and consistent application of EU competition law. ${ }^{2}$ However, questions have been raised as to the relevance and the legal effect of soft law for the competition policy and practice of NCAs. ${ }^{3}$

The role of European competition soft law, which can be traced back to the 1962 'Christmas notices', has indeed changed in the wake of Regulation $1 / 2003 .{ }^{4}$ It has been argued that 'the role of soft law in competition law enforcement has grown in impor-

DOI: $10.21552 /$ core/2020/4/5

* Leander Stähler, LLM, Research Assistant, Utrecht University School of Law. For correspondence: <l.s.stahler@uu.nl>. Professor Mariolina Eliantonio, Professor of European and Comparative Administrative Law and Procedure, Maastricht University Faculty of Law. For correspondence: <m.eliantonio@maastrichtuniversity.nl>.

1 Council Regulation (EC) 1/2003 on the implementation of the rules on competition laid down in Articles 81 and 82 of the Treaty (Regulation 1/2003) [2002] OJ L 1/1.

2 European Commision, 'White Paper on Modernisation of The Rules Implementing Articles 85 and 86 of The EC Treaty' COM(1999) 101 final, paras 104-107.

3 Senden wrote in 2003 on (at the time forthcoming) Regulation 1/2003: 'This development will also add urgency to the question

as to what relevance these [national] authorities have to give to Commission soft law acts relating to the interpretation and application of Article $81 \mathrm{EC}^{\prime}$ in Linda Senden, Soft Law in European Community Law: Its Relationship to Legislation (Hart 2003) 448; Pampel wrote that 'After the introduction of the [decentralization of the art 101(3)] exception system - combined with the stronger involvement of national authorities in the enforcement of European competition law - the question of the legal effects of the notices to the Member States is now increasingly raised' [translated by the author] in Gunnar Pampel, 'Europäisches Wettbewerbsrecht Rechtsnatur und Rechtswirkungen von Mitteilungen der Kommission im europäischen Wettbewerbsrecht' [2005] Europäische Zeitschrift für Wirtschaftsrecht 11, 11.

4 Oana Stefan, Soft Law in Court: Competition Law, State Aid and the Court of Justice of the European Union (Wolters Kluwer 2013) 24. 
tance' since the introduction of Regulation $1 / 2003 .{ }^{5}$ The White Paper on Modernisation of the Rules Implementing (what are now) Articles 101 and 102 TFEU envisioned that 'provided [that] individual decisions were upheld by the Court of Justice, then, notices and guidelines would come to form part of the rules that must be applied by national authorities'. ${ }^{6}$ Georgieva has argued that competition soft law 'supposedly diminishes the threat to consistent enforcement resulting from this new multi-level, multi-actor setting', in which the Commission has adopted the role of 'first among equals'. ${ }^{7}$ Consequently, Georgieva considered competition soft law to be 'indispensable for national enforcers'. ${ }^{8}$

The role that national institutions play in this dynamic has been discussed in academia. Analysis of the treatment of such competition soft law before national courts has been conducted in regard to British, Dutch, ${ }^{18}$ French and German courts. ${ }^{19}$ For the adjudicative level, Georgieva has demonstrated that courts show hesitation to engage with competition soft law, ${ }^{9}$ whilst they are likely to recognise soft law when it is used together with pertinent hard law in the Netherlands and the UK, ${ }^{10}$ as well as in France and Germany. ${ }^{11}$ For the practice of an NCA, Devine and Eliantonio have conducted research into the treatment of EU competition soft law by the UK Competition and Markets Authority (CMA). ${ }^{12}$ Their work demonstrated that, whilst the practice of the CMA retained consistency, no guidance was given

5 ibid 25.

6 Commission (n 2) para 86.

7 Zlatina Georgieva, 'Competition Soft Law in French and German Courts: A Challenge for Online Sales Bans Only?' (2017) 24

Maastricht Journal of European and Comparative Law 175, 176; Specifically, the Commission is empowered to 'relieve the national authorities (...) of their competence' (Regulation 1/2003, art $11(6))$ and NCAs are precluded from adopting decisions running counter to those of the Commission (Regulation 1/2003, art $16(2))$.

8 Zlatina Georgieva, 'Soft Law in EU Competition Law and Its Judicial Reception in Member States: A Theoretical Perspective' (2015) 16 German Law Journal 223, 227.

9 Georgieva, 'Competition Soft Law' (n 7) 193.

10 Zlatina Georgieva, 'The judicial reception of competition soft law in the Netherlands and the UK' (2016) 12 European Competition Journal 54,84

11 Georgieva, 'Competition Soft Law' (n 7) 193.

12 Thomas Devine and Mariolina Eliantonio, 'EU Soft Law in the Hands of National Authorities: The Case Study of the UK Competition and Markets Authority' (2018) 11 Review of European Administrative Law 49, 49-50.

13 ibid 71. by the CMA regarding the legal framework of its national duties with respect to the use of EU competition soft law. ${ }^{13}$ They conclude that, for this reason, ambiguity regarding the effect of soft law for NCAs persists. ${ }^{14}$

Moreover, the implications of Regulation 1/2003 and competition soft law have been subject to debate in German literature. Pampel, on the one hand, argued that the Commission ought to add remarks to notices stating that they do not bind Member States in the implementation of European competition law. ${ }^{15}$ Weitbrecht, on the other hand, argued that the Commission may require the application and observance of Commission guidelines both before national authorities and national courts. ${ }^{16}$ Consolidating this division, Pohlmann asserts that a 'strong factual bindingness' is undeniable; ${ }^{17}$ whether this 'factual bindingness' amounts to legal effect is not always clear. Thus, there seems to be some disagreement on what the binding legal effect of soft law is on the Bundeskartellamt (BKartA), namely the German NCA. ${ }^{18}$

The BKartA has been brought into focus by Kallmayer, who concluded that 'independently of the existence or non-existence of a true duty to consider [soft law], Commission guidelines are often laid down as the basis of Maßstabssätze ('benchmark rules'). ${ }^{19}$ In his paper, Kallmayer made little reference to the practice of the German NCA, limiting his discussion to two published documents. ${ }^{20}$

14 '[D] espite falling within the scope of the sincere cooperation obligation, the Grimaldi judgment only applies to national courts' in Devine and Eliantonio (n 12) 51.

15 Pampel (n 3) 13.

16 Andreas Weitbrecht, 'Das neue EG-Kartellverfahrensrecht' [2003] Europäische Zeitschrift für Wirtschaftsrecht 69, 72.

17 Petra Pohlmann, 'Keine Bindungswirkung von Bekanntmachungen und Mitteilungen der Europäischen Kommission' (2005) 10 Wirtschaft und Wettbewerb 1005, 1008.

18 Reinhard Ellger, 'Art 101 AEUV' in Ulrich Immenga and Torsten Mestmäcker (eds), EU Wettbewerbsrecht (5th edn, C.H. Beck 2012) para 73.

19 Axel Kallmayer, 'Die Bindungswirkungen von Kommissionsmitteilungen im EU-Wettbewerbsrecht - Mehr Rechtssicherheit durch Soft Law?' in Christian Calliess (ed), Herausforderungen an Staat und Verfassung (Nomos 2015) 677. Kallmayer posited two reasons for this practice: (1) the Commission's involvement of NCAs in the consultation process prior to the publication of new soft law gives room for the prior resolution of any disagreement, and (2) the 'apparent political perception' of NCAs in the ECN that uniform implementation of EU competition law can only be guaranteed by avoiding conflicting legal implementation. Kallmayer (n 19) 679.

20 Namely the Tätigkeitsbericht ('activity report') 2011/2012 and the Fallbericht ('case report') to decision B5-100-10 in Kallmayer (n 19) 678 . 
This research will go beyond the scope considered by Kallmayer in determining what the legal effect of EU soft law in the administrative decisions of the Bundeskartellamt is. To this end, this contribution proceeds as follows. Section II discusses the research method and the terms used in the research question, Section III provides an overview of the quantitative findings and Section IV offers a qualitative discussion of the findings after which Section $V$ concludes.

\section{Research Method}

\section{Theoretical Framework}

In EU governance, any instrument adopted by the institutions other than regulations, directives and decisions can be characterised as soft law. ${ }^{21}$ Snyder conceptualised this term to mean that instruments of soft law are instruments that have no legal binding force, but have practical effect. Senden has adopted a more extensive definition of soft law as 'rules of conduct' that 'have not been attributed legally binding force as such, but nevertheless may have certain (indirect) legal effects, and that are aimed at and may produce practical effects'.22 Utilising this definition, Senden classified soft law by its function and objective, thus identifying (1) preparatory and informative instruments, (2) interpretative and decisional instruments and (3) steering instruments. ${ }^{23}$

Additionally, the framework of soft law offered by Müller-Graff clarifies what the legal or practical effect of soft law can be. ${ }^{24} \mathrm{He}$ characterises soft law instruments by their 'binding element, ${ }^{25}$ which can take the form of a 'legal reference method' or a Selb-

\footnotetext{
21 Including but not limited to recommendations and opinions as mentioned in art 288 TFEU.

22 Senden, 'Soft Law' (n 3) 104

23 ibid 109-110.

24 Peter-Christian Müller-Graff, 'Das 'Soft Law' der europäischen Organisationen' (2012) 47 Europarecht 18, 27.

25 ibid 27.

26 ibid 28.

27 ibid.

28 Devine and Eliantonio (n 12) 52.

29 ibid 53

30 Ştefan (n 4) 57-67

31 Georgieva, 'Competition Soft Law' (n 7) 193.
}

stbindung ohne Rechtscharakter (lit. 'self-bindingness without legal character'), the use of which can result in legal effects. One specific legal effect of soft law that Müller-Graff identifies is that resulting from legal reference methods by a sovereign authority, ${ }^{26}$ such as the European Commission. ${ }^{27}$ As the BKartA adopts the role of the Commission in Germany, it supplants the Commission in Müller-Graff's framework for the purposes of this research, entailing that all decisions of the BKartA citing Commission soft law can give Commission soft law a form of legal effect.

In consolidation of this theoretical background, the framework used by similar studies ought to be considered. Regarding the impact of competition soft law, Georgieva's contribution has been significant. Devine and Eliantonio applied the framework devised by Georgieva with respect to the references to soft law by judicial authorities to the discussion of an NCA, dividing decisions into categories of either acceptance or refusal to recognise soft law. ${ }^{28}$ In doing so, they also considered instances in which implicit recognition and rejection of soft law is made. ${ }^{29}$ For the purposes of this research, implicit recognition and rejection of soft law will not be discussed, and only citations will be considered.

In her discussion on the treatment of soft law in courts, Ştefan established that more substantial references to soft law are generally more authoritative than brief references to soft law. ${ }^{30}$ Additionally, Georgieva has demonstrated for German and French courts that

[when] the content of Commission guidelines does reflect and/or clarify rules previously established in supranational hard law, judges readily endow soft law with legal effects through interpreting it together with the said hard law. ${ }^{31}$

Building on these ideas, the strength of the legal effect of soft law will be evaluated on the basis of its authority as highlighted by certain characteristics. Firstly, the type of reference is considered. References made in conjunction with an authoritative legal source will be considered to have a weaker legal effect, whilst references made to soft law as a self-standing authority will be considered to have a stronger legal effect. References made in conjunction with an authoritative legal source are references involving different forms of hard law, case law and other legal sources. Self-standing references to soft law will be 
subject to a second layer of analysis: the text of the cited soft law instrument will be considered to identify whether or not the cited soft law cites another legal source itself.

Secondly, Senden's classification of the objectives of soft law is considered. Soft law pursues interpretative objectives where it '[aims] at providing guidance as to the interpretation and application of existing Community law' and decisional objectives where it '[indicates] in what way a Community institution will apply Community law'.32 Specifically, competition soft law is decisional in nature, ${ }^{33}$ but decisional instruments 'may very well be, and often are, also interpretative to some extent.. ${ }^{34}$ Further, Senden sees a distinction between '[rules] drawn up with a view to explaining how EC law should be interpreted and those indicating how a Community institution charged with implementing and discretionary powers, in particular the Commission, will go about the exercise thereof in individual cases.. ${ }^{35}$ This research seeks to indicate that these objectives may not always be clearly separate, and considers the pursuit of each objective by the selected EU soft law measures and how they are used at the national level.

Finally, the type of reference, the objective pursued, as well as the text and context of BKartA decisions allows for a qualitative assessment of the strength of the legal effect.

\section{Methodology}

For the purposes of this research, the focal period will be that from 1 May 2004 until 31 December 2019, covering the date of entry into force of Regulation 1/2003 until the end of last year. From the pool of decisions handed down in this time frame, those explicitly referring to Commission soft law will be considered in order to assess the effect ascribed by the BKartA to EU soft law. In terms of instruments, the substantive competition soft law instruments mentioned in the following table will be considered.

The research was performed by searching for the abovenamed soft law instruments in the Entscheidungsdatenbank ('decisions database') available on the website of the BKartA. Specifically, the generic Leitlinie ('guideline'), Mitteilung ('Notice') and Bekanntmachung ('communication') were searched in order to yield a broad enough range of results to accom- modate the inconsistencies in citation style undertaken by the BkartA. ${ }^{36}$

Applying the theoretical framework discussed in Section II.1, the legal effects that Commission soft law has within German administrative decisions will be ascertained where these instruments of soft law are referenced.

\section{Quantitative Findings}

Annex 1 outlines the citations of soft law for each BKartA decision falling under the ambit of this research. ${ }^{37}$ As detailed in Annex 1, a total of 54 decisions were found, yielding a grand total of 312 references to the soft law instruments listed in Table 1 (see Appendix). The general overview of citations of the instruments of soft law is given by Table 2 (see Appendix).

At first sight, it would appear that the Article 101(3) Guidelines, the Effect on Trade Concept Guidelines and the Vertical Guidelines (2010), are particularly authoritative as they are the instruments with the most references. In the general scheme of competition law enforcement, this is comprehensible from the perspective of the BKartA. For example, an Article 101(3) exemption from liability under Article

\footnotetext{
Senden, 'Soft Law' (n 3) 109.

ibid 152.

ibid 150.

ibid 159.

36 This methodology has certain limitations. First of all, the decisions database is a wealthy source for decisions, but it is not exhaustive. The BKartA is explicitly obligated to publish decisions imposing fines for an infringement of arts 101 and 102 TFEU on its internet site since the addition of $\S 53(5)$ to the German Competition Act (GWB) in June 2017. Any decisions to impose fines published beyond this obligation are at the discretion of the BKartA and serve the general public relations of the body. Orders to bring an infringement to an end ( $\$ 32 \mathrm{GWB})$ and commitments ( $32 \mathrm{~b}$ GWB) must be published in the Federal Gazette in accordance with $\S 62$ GWB, whilst decisions that there is no reason for action (§ 32c GWB) may be published. In addition, the BKartA does not appear to follow a uniform method of citing legal sources. As indicated previously, some decisions make use of footnotes, whilst others make use of in-line references. Although infrequent, written errors also occur. These factors do not facilitate the task of analysing decisions.

37 For purposes of presentation, Table 2 abbreviates the names of soft law instruments. 'Art 101(3)' refers to the Guidelines on the Application of Art 101(3) TFEU, 'Tech' refers to the Guidelines on Technology Transfer Agreements, 'Trade' refers to the Effect on Trade Concept Guidelines, 'DM' refers to the De Minimis Notice, 'Horizontal' refers to the Horizontal Guidelines, 'RM' refers to the Relevant Market Definition Notice, and 'Vertical' refers to the Vertical Guidelines.
} 
101(1) may be an appealing legal defence for an undertaking to pursue, ${ }^{38}$ thus a discussion of its conditions as described in the Article 101(3) Guidelines strengthens the case which the BKartA may wish to argue. It is also pertinent to discuss the effect on trade, as 'may affect trade' is an essential condition of Article 101(1) liability. ${ }^{39}$ Lastly, as vertical agreements may be subject to a block exemption under the Block Exemption Regulation, and because this constitutes a viable legal strategy for undertakings, ${ }^{40}$ the discussion of the Vertical Guidelines and the interpretations and tests it provides is relevant.

Furthermore, it could also be said that the De Minimis Notices and the Horizontal Guidelines are also quite authoritative, as 27 and 16 decisions make reference to them respectively. Again, this is comprehensible from the perspective of the BKartA. The De Minimis Notices outline the conditions subject to which an agreement is understood to not create an appreciable restriction in the sense of Article 101(1). ${ }^{41}$ The lack of an appreciable restriction is a sound argument for an undertaking to potentially pursue. The Horizontal Guidelines outline provides interpretations and tests for the appraisal of agreements between competitors, which may for example provide a basis for arguing in favour of substantial economic benefits. ${ }^{42}$

However, as established in Section II.1, the understanding of 'authority' for the purposes of this research is not determined by sheer quantity. Rather, authority goes beyond the number of references to instruments and involves the type of reference made. As aforementioned, the type of reference made is determined by the involvement of other legal sources.

38 art 101(3) Guidelines, No 1: 'Agreements, decisions of associations of undertakings and concerted practices caught by Article [101(1] which satisfy the conditions of Article [101(3)] are valid and enforceable, no prior decision to that effect being required'.

39 Consolidated version of the Treaty on the Functioning of the European Union [2012] OJ C 326/47, Art 101(1).

40 Commission Regulation (EC) No 2790/1999 on the application of Article 81 (3) of the Treaty to categories of vertical agreements and concerted practices [1999] OJ L 336/21; Commission Regulation (EU) No 330/2010 on the application of Article 101(3) of the Treaty on the Functioning of the European Union to categories of vertical agreements and concerted practices [2010] OJ L 102/1.

41 De Minimis Notice (2001), No 2; De Minimis Notice (2014), No

42 Horizontal Guidelines (2001), No 3; Horizontal Guidelines (2010), No 2

43 Note that the total here exceeds 60 as several references were in conjunction with multiple other legal sources.
Of the total 312 references to competition soft law made by these decisions, a total of 252 were selfstanding references. Out of these 252 self-standing references, 43 were without reference to a specific provision of the soft law instrument, whilst the remaining 209 indicated some form of a Randnummer ('margin number'), paragraph or page number.

The remaining 60 references were made in conjunction with some other legal source. Out of these 60 remaining references: ${ }^{43}$

- 14 were in conjunction with other (European or BKartA) soft law in accordance with Senden's definition in Section II.1,

- 20 were in conjunction with commentaries, a medium of legal literature commonly used in Germany for legal practice, discussed further in Section IV.3,

- 2 were in conjunction with another BKartA or Commission decision, administrative decisions taken by either the Commission or BKartA enforcing competition law,

- 27 were in conjunction with (European and/or German) case law, any judgment by a European or German court,

- 4 were in conjunction with hard law, here understood as European and German legislation.

Applying the understanding of legal effect elucidated in Section II.1, the fact that 252 references to soft law are self-standing suggests a strong legal effect of competition soft law. Moreover, the fact that only 31 references were made to soft law in conjunction with either case law or hard law suggests that instances, where the legal effect is weaker, make up a rather small portion of the total references.

As mentioned above, 209 self-standing references to soft law could be identified where a margin, paragraph or page number was indicated. Of those, the analysis revealed that 109 references were 'fully' selfstanding; ie references were made in a decision to a specific provision of soft law and that cited soft law provision does not itself refer back to some other legal source. This means that for the remaining 100 references indicating specific provisions of soft law, these provisions of soft law made further reference to another legal source.

Table 3 (see Appendix) includes references to soft law which were made in conjunction with some other legal source and references to soft law where the provision of soft law cited itself refers back to anoth- 
er legal source. As a consequence of this analysis, 160 $(100+60)$ references cited a provision of soft law or involved another legal source.

\section{Qualitative Discussion}

The following discussion will seek to 'flesh out' the legal effect of the types of references identified above by discussing pertinent examples from decisions. The discussion of the examples, the text and the context of decisions, is useful for gauging the strength of the observable legal effects.

As is clear from Section II.1, decisional and interpretative objectives differ, but can also overlap. Concretely, Senden outlined that decisional objectives 'go further than mere interpretation'. ${ }^{44}$ Whereas the legal effect of interpretative acts is that of an interpretation aid, decisional acts have binding effects beyond this. ${ }^{45}$ Applying this to references to soft law, instances where a reference is decisional, ie used to indicate how power is being exercised, will be deemed to have a stronger legal effect than instances where references are interpretative, ie used to provide guidance as to the interpretation of law. ${ }^{46}$

\section{1. 'Fully' Self-Standing References to Soft Law}

'Fully' self-standing references to soft law isolate soft law as the sole legal source in a specific passage of the BkartA decisions.

These types of references serve, first of all, a decisional objective. This is demonstrated, for example, in a decision on the coordinated distribution of coal and grill igniter. ${ }^{47}$ Here, No 167 of the Horizontal Guidelines (2011) is used as the sole source (save Article 101 TFEU) to establish that horizontal distribution agreements are problematic. ${ }^{48}$ The decision further elaborates on how this is to be assessed by referring to Nos 230-236 of the Horizontal Guidelines. ${ }^{49}$ Thus, the horizontal relationship is assessed on the basis of soft law. The decision explains why the BKartA has decided to accept the commitments offered by the addressee on the sole basis of Nos 175-180 of the Horizontal Guidelines. Using solely soft law to fulfil a decisional objective in such a decision can be said to bestow soft law with a significantly strong legal effect.
'Fully' self-standing references to soft law are also made frequently in support of an interpretative objective. Specifically, they are crucial for the concretisation of provisions of hard law. One instance of this is observed in a decision regarding technology transfer agreements for producers of sand-lime bricks. ${ }^{50}$ In this decision, a fully self-standing reference is made to Technology Transfer Guidelines (TTG) No $53{ }^{51}$ which elaborates on the scope of Commission Regulation 772/2004 on the application of Article $81(3)$ of the Treaty to categories of technology transfer agreements. ${ }^{52}$ The TTG explains that the Regulation also covers non-assertion and settlement agreements. This case indicates that self-standing references serve an interpretative objective and thus concretise existing hard law; soft law can also be said to have a strong legal effect because it is used to provide hard law with a specific concrete meaning which conditions the final BkartA decision.

It should finally be noted, with respect to selfstanding references, that a significant portion of these references are made without referring to a specific provision of the relevant instrument. A pertinent example is offered by a decision on the cooperation between insurers for the assessment of pecuniary damage liability risks of auditing professionals. ${ }^{53}$ In this instance, the Relevant Market Definition Notice is first mentioned with no reference to a specific provision. ${ }^{54}$ Exact provisions are referenced on the subsequent page. ${ }^{55}$ Another way in which such self-standing references without reference to a provision are made is as a brief head-nod; e.g. in a decision pertaining to 'take or pay' clauses in gas supply

\footnotetext{
4 Senden, 'Soft Law' (n 3) 140-141.

45 Linda Senden, 'Soft Post-legislative Rulemaking: A Time for More Stringent Control' (2013) 19 European Law Journal 57, 62

46 cf s II. 1.

7 Bundeskartellamt, Decision B3-93-15.

8 Bundeskartellamt, Decision B3-93-15, 8-9.

Bundeskartellamt, Decision B3-93-15, 9.

Bundeskartellamt, Decision B01-165-01.

Bundeskartellamt, Decision B01-165-01, 12.

52 Commission Regulation (EC) No 772/2004 on the application of Article 81 (3) of the Treaty to categories of technology transfer agreements [2004] OJ L 123/11.

53 Bundeskartellamt, Decision B4-31-05.

54 ibid 12-13.

55 ibid 13.
} 
contracts, ${ }^{56}$ the De Minimis Notice (2001) is referred to briefly only to be dismissed as inapplicable, ${ }^{57}$ omitting further engagement with the instrument. One final way in which such self-standing references are made without reference to provisions is by referring to specific aspects of the content of the soft law in strument without distinguishing the exact provision. This is done in a decision on the coordination between television stations for the introduction of encryption, ${ }^{58}$ wherein the BKartA notes the market share limits to qualify for consideration under the De Minimis Notice (2001), yet omits the exact provision that stipulates this. ${ }^{59}$ It is difficult to determine how the BKartA hopes to realise the decisional objective of soft law by using such self-standing references, as it does not always engage explicitly with the content of the soft law instruments. On the other hand, such references can be indicative of how the BKartA seeks to fulfil the interpretative objective more generally, providing insight to its discretionary assessment. Thus, the BKartA can be regarded as ascribing some small legal effect to soft law through such references.

\section{References to Soft Law and Other Soft Law}

References to soft law that involve other soft law play an important role in establishing the legal effects of soft law generally, including that of instruments be-

\footnotetext{
56 Bundeskartellamt, Decision B10-10-10.

57 ibid 7.

58 Bundeskartellamt, Decision B7-22-07.

59 ibid 32.

60 Bundeskartellamt, Decision B4-9-11.

61 ibid 86; ie they are normally appreciable if the parties to the agreement have a market share of more than $10 \%$ (for competing undertakings) or $15 \%$ (for non-competing undertakings) on the market affected by the agreement.

62 Bundeskartellamt, Decision B7-46-13.

63 Bundeskartellamt, 'Information on the competitive assessment of cooperations in the expansion of optical fibre in Germany' (19 January 2010) <https://bit.ly/324shwj> accessed 19 April 2020.

64 Bundeskartellamt, Decision B7-46-13, 28.

65 Bundeskartellamt, Decision B9-66-10.

66 ibid 43.

67 ibid; the relevant geographic market comprises the area in which the undertakings concerned participate in the supply and demand of relevant goods or services, in which the conditions of competition are sufficiently homogeneous and which differs significantly from neighbouring areas with appreciably different conditions of competition
}

yond the scope of this research. By putting different soft law instruments on an equal playing field as complementary instruments of competition law in the pursuit of interpretative and decisional objectives, the legal effect of these instruments can be strengthened.

Regarding the decisional objective, references in conjunction with other soft law are used to amplify the legal effect of the relevant competition soft law measure. This is especially notable where the BKartA uses its own soft law in conjunction with Commission soft law. An example can be found in a decision pertaining to an agreement by financial institutions on a uniform fee policy for electronic cash transactions. ${ }^{60}$ In this decision, No 7 of the De Minimis Notice (2001) is used in conjunction with No 8 seq of the Bagatellbekanntmachung to decide when a restriction on competition is appreciable. ${ }^{61}$ Consequently, these benchmark percentages, as stipulated by both soft law instruments, are used as the authority on the basis of which the BKartA decides whether an agreement appreciably restricts competition.

A similar situation is exhibited by a decision pertaining to an agreement between telecommunication companies on cooperation in the broadband connections sector. ${ }^{62}$ Therein, the BKartA uses the Article 101(3) Guidelines in conjunction with the BKartA's Hinweise zur wettbewerbsrechtlichen Bewertung von Kooperationen beim Glasfaserausbau in Deutschland. $^{63}$ There, page 107 of the Article 101(3) Guidelines regarding qualitative efficiencies is used together with pages 25 and 26 of the BKartA document to assert that the parties must demonstrate in detail that the cooperation will increase the number of customers that can be supplied with higher quality broadband connections. ${ }^{64}$ Again, this establishes a test, here for establishing qualitative efficiencies in a broadband situation, based on which the BKartA decides. Therefore, the legal effect of soft law is particularly strong in these instances.

A reference in conjunction with other instruments of soft law can also result from pursuing interpretative objectives. A pertinent example of this is contained in a decision regarding the inclusion of a 'best price' clause in contracts between a hotel portal provider and hotels. ${ }^{65}$ In this decision, No 8 of the Relevant Market Notice is used in conjunction with No 88 of the Vertical Guidelines (2010). ${ }^{66}$ Specifically, these instruments offer an interpretation of the relevant geographic market. ${ }^{67}$ This showcases how 
the interpretation of concepts relevant for a variety of cases, such as that of the relevant market, is adequately addressed by the concurrent consideration of two competition soft law instruments. This particular example showcases an even stronger legal effect, as the concretisation here is not of a particular instrument of hard law.

Reference to other soft law by provisions of referenced soft law encompasses 26 out of the total 40 references to other soft law. Broadly, these types of references further the interpretative objective of soft law, offering supplemental considerations on concepts of competition law. A BKartA decision on the joint buying agreement by hollow brick producers is a fitting example of this. ${ }^{68}$ This decision refers to No 50 of the Effect on Trade Concept Guidelines to demonstrate the BKartA's understanding that the appreciable effect on trade in the present case is not a priori excluded. ${ }^{69}$ No 50 of the Effect on Trade Concept Guidelines itself refers to the De Minimis Notice (2001) and a Commission Recommendation ${ }^{70}$ to discuss the quantification of an appreciable effect on trade.

A further example is a decision pertaining to a joint buying agreement for waste glass. ${ }^{71}$ In this decision, the BKartA uses No 106 of the Article 101(3) Guidelines to assert that account must be taken of Article 102 TFEU, in order to determine the conditions for an Article 101(3) exemption..$^{72}$ No 106 of the Article 101(3) Guidelines discusses the interplay between Articles 101(3) and 102 TFEU more clearly and refers to provisions of the Vertical Guidelines (2000) and the Horizontal Guidelines (2001) to do so. The reference to these other soft law instruments provides further explanation on concepts of competition law as treated by different soft law instruments.

\section{References to Soft Law and Commentaries}

Commentaries are a genre of legal literature in the German legal tradition, which elaborate on legal concepts and issues and the interaction of one provision with other laws and principles.

To serve the decisional objective, commentaries and Commission soft law are sometimes used in conjunction by the BKartA. This is exemplified in a decision against the statute of an ophthalmologists collective. ${ }^{73}$ This decision establishes the test that a restriction of

competition by object exists when, upon objective interpretation of the contract, the restriction is capable of restricting competition. ${ }^{74}$ This test is used to justify the assertion that the contract between the addressee parties has as its object and effect the restriction of competition. ${ }^{75}$ This test is referenced from No 27 of the Horizontal Guidelines and a Nordemann contribution to a Loewenheim/Meessen/Riesenkampff commentary on competition law.

To serve the interpretative objective, commentaries and soft law often contribute together to elaborate on the reasoning of the BKartA. A relevant example is given by a decision regarding a lottery block's decision to not accept certain revenues from commercial gaming agents. ${ }^{76}$ In this decision, the BKartA uses the Relevant Market Notice in conjunction with a contribution by Schröter to a Groeben/Schwarze commentary on the TFEU to demonstrate its understanding of the relevant product market. $^{77}$

Another example is given by a decision which pertained to various restrictions imposed on the retail of contact lenses. ${ }^{78}$ Therein, the norm that a concerted practice can be established without the dealers themselves having to make contact with each other is cited from a Langen/Bunte commentary on European Competition Law in conjunction with No 227 of the Vertical Guidelines (2000) and thus clarifies the interpretation of when concerted practices can be established.

Delving deeply into the discussion of the legal effect of commentaries in the German legal system would go beyond the scope of this research. However, given their legal merit, the use of soft law in con-

68

69 ibid 6.

70 (SM

71 Bundeskartellamt, Decision B4-1006-06.

72 ibid 84.

73 Bundeskartellamt, Decision B3-11-13-1.

74 ibid 12.

75 ibid.

76 Bundeskartellamt, Decision B10-148-05.

77 Bundeskartellamt, Decision B10-148-05, 55; ie that it comprises all services which are regarded as interchangeable or substitutable by the customers, by reason of their characteristics, prices and intended use.

78 Bundeskartellamt, Decision B3-123-08 
junction with commentaries is a significant boost to the legal strength of soft law. It can be said that commentaries share similarities with competition soft law instruments in the pursuit of their interpretative objectives. Both provide guidance to legal actors on the interpretation of legal concepts. Thus, it is understandable why commentaries and soft law can go hand in hand for an actor such as the BKartA. Nevertheless, commentaries have an authoritative, wellestablished standing in German legal practice, whilst soft law is a relatively young development. ${ }^{79}$ Overall, it can be asserted that the use of commentaries in conjunction with competition soft law strengthens its legal effect more than it weakens it.

\section{References to Soft Law and Other Decisions}

Generally, NCAs only have the power to apply Articles 101 and 102 TFEU 'in individual cases'. ${ }^{80}$ Likewise, decisions of the Commission are addressed to 'the undertakings and associations of undertakings involved [with the infringement of Articles 101 and 102 TFEU], ${ }^{81}$ Although the power of the Commission

79 cf Stefan (n 4) 8.

80 Regulation 1/2003, art 5.

81 Regulation 1/2003, art 7(1).

82 Regulation 1/2003, art 11(6).

83 Christina Oelke, Das Europäische Wettbewerbsnetz: Die Zusammenarbeit von Kommission und nationalen Wettbewerbsbehörden nach der Reform des Europäischen Kartellverfahrensrechts (Nomos 2006), 69.

84 B4-1006-06. Referred to in S IV.2

85 Rennet (Case IV/29.011) Commission Decision 80/234/EEC [1979] OJ L 51/19; National Sulphuric Acid Association (Case IV/27.958) Commission Decision 80/917/EEC [1980] OJ L 260/24; it should be noted that this reference also cites a CJEU case and a case before the German Supreme Court (BGH).

86 Bundeskartellamt, Decision B4-1006-06, 35.

87 ibid.

88 Bundeskartellamt, Decision B9-121-13.

89 ibid 113; ie parties wishing to benefit from an exemption must explain and demonstrate why alternatives to the agreement which appear realistic and less restrictive of competition would be significantly less efficient.

90 'The parties must only explain and demonstrate why such seemingly realistic alternatives to the agreement would be significantly less efficient' in: art 101(3) Guidelines, No 75.

91 See regarding the bindingness of soft law for the Commission itself: Case C-189/02 Dansk Rørindustri and Others $v$ Commission [2005] ECLI:EU:C:2005:408.

92 Bundeskartellamt, Decisions B01-165-01, 11; B10-148-05, 112; B10-148-05, 161; B10-148-05, 193; B3-64-05, 54; B4-9-11, 88. to relieve NCAs of their competence to apply Articles 101 and 102 of the TFEU was established by Regulation $1 / 2003,{ }^{82}$ there is no formal hierarchy of Commission decisions to decisions of NCAs, nor is there a hierarchy of previous BKartA decisions on future BKartA decisions. ${ }^{83}$ Ergo, it is not outright obvious why the BKartA would cite soft law measures in conjunction with earlier Commission or BkartA decisions to achieve interpretative and decisional objectives. However, this could be in the interest of respecting the principles of legitimate expectations and legal certainty.

In a decision regarding the market for waste glass, ${ }^{84}$ No 119 of the Horizontal Guidelines (2001) is referenced in conjunction with inter alia two Commission Decisions. ${ }^{85}$ These references underline the interpretation that joint buying arrangements directly affected the markets on which the products covered by the agreement are purchased ${ }^{86}$ thus serving the interpretative objective of soft law. However, it is clear here that the effect of the soft law instrument is weaker, given that No 119 of the Horizontal Guidelines (2001) states that joint buying 'may affect,' which is a more moderate stipulation than 'directly affect' the relevant markets, which was instead the conclusion reached by the BKartA. This latter stipulation can therefore not be authoritatively attributed to the soft law instrument. In this instance, it is equally attributable to a Commission Decision or European case law. ${ }^{87}$

In a decision regarding the 'best price' clause in contracts between a hotel portal provider and hotels, ${ }^{88}$ a further example is given. Therein, No 75 of the Article 101(3) Guidelines is referenced in conjunction with BKartA decision B9-66-10 to outline a requirement for benefitting from an Article 101(3) TFEU exemption. ${ }^{89}$ This reference is decisional in nature as it lays out a test for when a party may benefit from an Article 101(3) exemption, and the Article 101(3) Guidelines clearly mirror this rule. ${ }^{90}$ Thus, the decisional objective of soft law goes hand in hand with the decision previously issued, with the soft law having noticeable legal effect.

In total, there are 12 instances where a soft law provision cited by the BKartA cites a Commission decision. As the author of both decisions and soft law, the Commission has a vested interest in being consistent with its practice. ${ }^{91}$ One particular provision is cited 6 times by different BKartA decisions: No 49 of the Article 101(3) Guidelines. ${ }^{92}$ This provision dis- 
cusses efficiency gains and outlines what types of economic benefits and pro-competitive effects can be taken into account in the assessment of an efficiency gain. ${ }^{93}$ An example of an interpretative provision, ${ }^{94}$ No 49 also includes a reference to a Commission Decision to assert that efficiencies are not assessed from the subjective point of view of the parties. ${ }^{95}$ Out of these six references, only one directly engages with the fact that efficiency gains are not assessed from a subjective point of view. ${ }^{96}$ Consequently, this indicates that for the remaining 5 references, soft law retains a significant legal effect in the interest of the interpretative objective.

Overall, references made by soft law instrument to Commissions or BKartA decisions do not rule out a potentially strong legal effect of soft law. Competition soft law can indeed contribute as an interpretative guidance to supplement a decisional rule laid down by an administrative decision, and additionally contribute as a decisional assessment. This makes sense given that the decisional objective is defined by 'indicating how the Commission intends to apply EU law in individual cases, ${ }^{97}$ and which is then manifested by the administrative decisions issued by the Commission or the national competition authorities.

\section{References to Soft Law and Case Law}

As shown in Table 3, the number of references to soft law in conjunction with case law is 27 , whilst the total number of citations involving case law is 103. At approximately a third of all references identified, this is a significant portion of the references analysed.

As a civil law jurisdiction, case law in Germany generally does not have the same precedential value that it might have under other jurisdictions, though it is authoritative via its function of concretising and complementing norms. ${ }^{98}$ The case law of the European courts as a subset of case law plays a different role. ${ }^{99}$ The function of case law to concretise legal norms is comparable to the interpretative objective of competition soft law. Additionally, the function of case law to apply the law to individual cases bears resemblance to the decisional objective of soft law. The implementation of values to individual cases by courts is similar to the Commission's objective of indicating the exercise of its powers to individual cases, as theorised by Senden. ${ }^{100}$ Some competition soft law is arguably abstract and general in nature, yet with the ability of the courts to partake in 'evaluative recognition,' ${ }^{101}$ case law has greater authority than soft law. This is demonstrably true for the decisional practice of the BKartA.

Examples of competition soft law being used in conjunction with case law are numerous. In a BKartA decision pertaining to a joint selling arrangement for coniferous wood, ${ }^{102}$ one particular example is offered. Nos 23-32 of the Effect on Trade Concept Guidelines are used together with a CJEU judgment ${ }^{103}$ to establish the BKartA's understanding of the effect on trade of a joint selling arrangement. ${ }^{104}$ Thus, the BKartA uses the elaboration contained in soft law and case law to outline the legal interpretation of the ability to affect trade between Member States. Similar to this, another example is given by a lottery block decision. ${ }^{105}$ In this decision, No 23 of the Effect on Trade Concept Guidelines is used in conjunction with page 8 of the German Soda-Club case ${ }^{106}$ to assert when a risk of trade being affected between Member States shall be deemed to exist. ${ }^{107}$ In a decision pertaining to long-term purchase obligations and actual supply requirements imposed by a gas supply contract, the decisional objective comes into play. ${ }^{108}$ This

93 art 101(3) Guidelines, No 49

94 art 101(3) Guidelines, No 49 stipulates what is to be interpreted as an efficiency gain and what is not.

95 Van den Bergh Foods Limited (Case Nos IV/34.073, IV/34.395 and IV/35.436) Commission Decision 98/531/EC [1998] OJ L 246/1.

96 Bundeskartellamt, Decision B10-148-05, 193

97 Senden, 'Soft Post-legislative Rulemaking' (n 53) 60.

98 On the basis of art 20(3) of the German Basic Law (BVerfGE 34, 269 - 'Soraya'; BVerfGE 66, 116 - 'Springer/Wallraff')

99 A role akin to a constitutional court, see Bernhard Wegener, 'Art 19 [Gerichtshof der Europäischen Union]' in Christian Calliess and Matthias Ruffert (eds), EU-Vertrag (Lissabon) (5 ${ }^{\text {th }}$ edn, Beck 2016) para 18.

100 See s II. 1

101 Monika Jachmann-Michel, 'Article 95', para 13 in Theodor Maunz and Günter Dürig (eds), Grundgesetz (86th edn, C.H. Beck 2019).

102 Bundeskartellamt, Decision B1-71-12.

103 Case C-475/99 Ambulanz Glöckner v Landkreis Südwestpfalz [2001] ECLI:EU:C:2001:577, para 48.

104 Bundeskartellamt, Decision B1-72-12, 159; ie that the ability of the joint selling arrangement to affect trade between Member States and its actual effect result from the type of goods covered, the type of agreement, taking into account the legal and factual context.

105 Bundeskartellamt, Decision B10-148-05. See s IV.3.

106 OLG Düsseldorf, Decision of 12 April 2006 VI - Kart 5/06 (V) 'Soda-Club'.

107 Bundeskartellamt, Decision B10-148-05, 148

108 Bundeskartellamt, Decision B8-113-03-1. 
decision uses No 119(6) seq. of the Vertical Guidelines (2000) in conjunction with a CJEU judgment ${ }^{109}$ to establish a foreclosure effect. ${ }^{110}$ Thereby, a soft law instrument is used to supplement the CJEU judgment regarding certain types of vertical foreclosure effects.

These examples demonstrate the legal effect that soft law has in conjunction with relevant case law. Using soft law as an elaboration, the legal reasoning followed by a court contributes to the fulfilment of the interpretative objective of soft law, endowing it with moderate legal effect. Where the reasoning used is identical in soft law and case law, the contribution of soft law (and, therefore, its legal effects) might be said to be weaker. A reference to soft law in decisional considerations of the BKartA may be useful for an addressee, yet the citation of a court's judgment perpetuates 'the capacity of a court to authoritatively determine the content of a community's normative structure.'111 The fact that case law is recognised by the BVerfG, unlike soft law, further suggests that interpretation by courts is more authoritative. Whatever lacunae case law leaves open, soft law nevertheless has the potential of filling it.

References to soft law, where the cited soft law provisions in turn refer to case law, are also numerous. These references within soft law instruments are

109 Case C-234/89 Stergios Delimitis v Henninger Bräu AG [1991] ECLI:EU:C:1991:91.

110 Bundeskartellamt, Decision B8-113-03-1, 18; ie that suppliers are part of a network of parallel long-term contracts which, taken as a whole, bring about a prohibited foreclosure effect.

111 Alec Stone Sweet, 'Judicialization and the Construction of Governance' (1999) 32 Comparative Political Studies 147, 164 in: Stefan (n 4) 38 .

112 Alec Stone Sweet, 'The European Court of Justice' in Paul Craig and Gráinne de Búrca (eds), The Evolution of EU Law (Oxford University Press 2011) 147

113 the guidelines are without prejudice to the interpretation that may be given by the $[\mathrm{GC}]$ and the $[\mathrm{EC}]]^{\prime}$ in Vertical Guidelines (2000), No 4; '[t]he Commission's interpretation of 'relevant market' is without prejudice to the interpretation which may be given by the [EC] or the [GC]' in: Relevant Market Notice, No 6. Examples in the substantive provisions of competition soft law include: Horizontal Guidelines (2011), No 25; art 101(3) Guidelines, No 49; Effect on Trade Concept Guidelines, No 13.

114 Commission Regulation (EC) No 2790/1999 on the application of Article 81 (3) of the Treaty to categories of vertical agreements and concerted practices [1999] OJ L 336/21; Commission Regulation $330 / 2010$ on the application of Article 101(3) of the Treaty on the Functioning of the European Union to categories of vertical agreements and concerted practices [2010] OJ L 102/1.

115 Maria Greismann, 'Art 288 AEUV' in Hans von der Groeben, Jürgen Schwarze and Armin Hatje (eds), Europäisches Unionsrecht (7th edn, C.H. Beck 2015) para 4.

116 Bundeskartellamt, Decision B3-123-08; see s IV.3.

117 Regulation 2790/1999, art 4(b) and (c). all to rulings of both EU Courts. The Commission practice of referring to CJEU case law in its own soft law measures aligns with what Stone Sweet calls the 'capacity of the Court to alter the underlying 'rules of the game' that govern policy-making in any given field'. ${ }^{112}$ This is indeed the case with the soft law instruments in question, which frequently include statements referring to the authority of the CJEU, ${ }^{113}$ Such statements show that the Commission seeks to give the reader the impression that the content of the instrument offers a reflection of CJEU jurisprudence. Thus, these 76 references are a testament to the attempts of the Commission in crafting soft law in line with European case law. Nevertheless, in the abovementioned cases, the BKartA made the decision to refer to soft law instead of case law, ascribing the soft law instruments a slight but nevertheless noteworthy legal effect.

Overall, despite the lack of an obligation to actively involve case law, the BKartA uses it to complement its reasoning. A weak to moderate legal effect can be observed in the BKartA's practice of using the two legal sources in conjunction to fulfil interpretative objectives, whilst the decisional strength of case law generally overshadows contributions thereto by soft law. The reference to soft law where that soft law refers to earlier case law interestingly establishes a somewhat stronger legal effect for soft law, as the BKartA chooses to refer to soft law and not to relevant case law.

\section{References to Soft Law and Hard Law}

Hard law is inherent to all decisions of the BKartA. Naturally, all decisions considered by this research are decided on the basis of Articles 101 and 102 TFEU. The four instances of hard law used in conjunction with soft law all elaborate on instruments of EU secondary legislation, namely the Vertical Block Exemption Regulations (VBER or Vertical BER). ${ }^{114}$ It is settled law that European Regulations override national law and that they are directly applicable in Member States, thus formally outranking soft law. ${ }^{115}$

For references to soft law made by the BKartA in conjunction with hard law, the decisional objective of soft law is not fulfilled. This is due to the fact that soft law in conjunction with hard law is largely an interpretative aid. In a decision on the contact lenses market, ${ }^{116}$ the VBER ${ }^{117}$ is used in conjunction with 
No 52 seqq of the Vertical Guidelines (2000) to assert that no exemption for the infringement was applicable. ${ }^{118}$ This assertion is somewhat decisional, but in consideration of the VBER, the chief contribution of soft law is its interpretation of free-riding, ie a contribution towards the interpretative objective of soft law.

Another pertinent example is given by a decision regarding agreements between ticket system service providers and event organisers. ${ }^{119}$ In this decision, the VBER ${ }^{120}$ is used in conjunction with No 12 seqq of the Vertical Guidelines (2010) to classify the agreement as an agency agreement. ${ }^{121}$ In a separate instance of this same decision, the Regulation ${ }^{122}$ is used in conjunction with No 21 of the Vertical Guidelines (2010) to discuss anticompetitive effects. ${ }^{123}$ Given the brevity of the relevant hard law provision defining the term 'buyer', the provisions of the Vertical Guidelines serve as an important interpretative tool. The last instance of soft law in conjunction with hard law is given by the hotel portal decision. ${ }^{124}$ In this decision, the VBER ${ }^{125}$ is used in conjunction with No 93 of the Vertical Guidelines (2010) to define the determination of market share. ${ }^{126}$ These four references to soft law in conjunction show that the effect of soft law is linked to the interpretative objective.

There are 14 references to soft law provisions which refer to hard law. ${ }^{127}$ One provision of soft law that is cited by two decisions is No 11 of the De Minimis Notice (2001), which is cited in the ASICS decision and the sand-lime brick decision. ${ }^{128}$ This provision refers to two Commission Regulations ${ }^{129}$ to determine 'hardcore' agreements between competitors that do not benefit from the exemption from the application of Article 101(1) TFEU stipulated by No 7 of the De Minimis Notice (2001), thus a contribution towards the decisional objective of soft law. ${ }^{130}$ This exact part of No 11 referencing hard law is cited by the ASICS decision, and thus the legal effect can be attributed to hard law, whilst in the sand-lime brick decision, application of the provision is limited to asserting that a hardcore restriction is present. In consideration of the context of the sand-lime brick decision, it is clear that the agreement in question is vertical and not horizontal, and thus falls outside the scope of the part of the provision referencing hard law. In the ASICS case, the decisional element can be attributed to hard law, whilst the decisional element of the sand-lime brick decision is unique to the provision of soft law. Therefore, soft law can retain legal effect, but in certain instances, hard law can supersede the legal effect of soft law.

\section{Conclusion}

This research set out to establish the legal effects of soft law in the decisions of the BKartA. The analysis has revealed that the BKartA has made 312 references to selected soft law measures issued by the European Commission. This shows that soft law has established itself as an acceptable tool in the fulfilment of the BKartA's mandate to enforce Articles 101 and 102 TFEU.

However, what this contribution has also shown is that legal effects and their strength cannot be deduced by sheer quantity and the referencing to soft law in the BkartA's practice displays a number of significant variations, ranging from 'fully' self-standing references, where soft law constitutes the sole legal basis for a certain part of the BartKA's decision, to references to EU soft law which referred in turn to other sources, to references made in conjunction with other sources.

'Fully' self-standing references have been considered to have the strongest legal effects, and references made to EU soft law in conjunctions other soft law or commentaries can be considered to have a

\footnotetext{
118 Bundeskartellamt, Decision B3-123-08, 11.

119 Bundeskartellamt, Decision B6-132-14-2.

120 Regulation 330/2010, art 1(1)(h).

121 Bundeskartellamt, Decision B6-132-14-2, 31.

122 Regulation 330/2010, art 1(1)(h).

123 Bundeskartellamt, Decision B6-132-14-2, 31; ie that the existence of an agency agreement does not preclude consideration of anticompetitive effects on buyers and customers.

124 Bundeskartellamt, Decision B9-66-10; see s IV.2.

125 Regulation 330/2010, art 7(a).

126 Bundeskartellamt, Decision B9-66-10, 72; ie that market share is to be determined by using value data.

127 NB: Since competition soft law issued by the Commission focuses on aspects of European competition rules, no such reference are made to German or other national law.

128 Bundeskartellamt, Decision B1-116-04, 31; B2-98-11, 81. See s IV.1.

129 Commission Regulation (EC) No 2658/2000 on the application of Article 8183 ) of the Treaty to categories of specialisation agreements [2000] OJ L 304/3; Commission Regulation (EC) No $2659 / 2000$ on the application of Article 8183) of the Treaty to categories of research and development agreements [2000] OJ L 304/7.

130 De Minimis Notice (2001), No 11(1).
} 
similarly strong legal effect. Furthermore, references that also refer to other decisions, case law and hard law were also considered to have significant legal effect.

The findings of this research demonstrate a difference in treatment of competition soft law to that found by comparable research. Whereas Devine and Eliantonio found that soft law was only accepted by the CMA where it refers to EU case law, ${ }^{131}$ the BKartA appears to be more comfortable with full reliance on soft law instruments. Similarly, the BKartA is less hesitant than German courts to endow legal effects not previously endorsed by stronger legal authority, as demonstrated by Georgieva. ${ }^{132}$ Concretely, in instances where soft law is used by the BKartA to fulfil decisional objectives, this creates a legal effect which is on a similar level to more authoritative legal sources. Moreover, the use of soft law as an inter-

131 Devine and Eliantonio (n 12) 71.

132 Georgieva, 'Competition Soft Law' (n 7) 193.

133 Devine and Eliantonio ( $n$ 12) 72; It is of course not the role of the BKartA to highlight defects in its legal argumentation, however, further insights from enforcement could address this question.

134 For instance, by drawing inspiration from the best practices of systematic content analysis. see: Mark A. Hall and Ronald F.

Wright, 'Systematic Content Analysis of Judicial Opinions' (2008) 96 California Law Review 63. pretative aid is a strong indicator of the value ascribed to soft law as a legal source by the BKartA.

Although this research has clarified the legal effect of competition soft law as enforced by the BKar$t A$, it raises questions for future discussion. First of all, further research should be carried out as to whether and how the relevant CJEU's case law and the soft law consolidating it overlap or, conversely, diverge. Furthermore, why references are made in BKartA's decisions could be further explored. In the first place, it remains unclear what the rationale of the BKartA is for making reference to soft law. As is evident from the majority of references identified here, a number of other instruments are available to enforcers that reflect the same rules as those provided by soft law instruments. In the second place, it is not clear whether the BKartA has considered the concern that the Commission codified an interpretation of CJEU case law favouring itself. ${ }^{133}$ Building on the insights of this research, for instance, further interEuropean comparisons should be made, thus contributing to discussions on the role of national administrative authorities as enforcers of EU law. Finally, this research and other research on EU competition authorities' use of soft law ought to be reviewed in light of appropriate quantitative and qualitative methodologies. ${ }^{134}$ 


\section{Appendix}

Table 1. List of EU Soft Law Measures Covered by the Search

\section{Soft Law Instruments}

Article 101(3) Guidelines a

De Minimis Notices ${ }^{b}$

Effect on Trade Concept Guidelines c

Horizontal Guidelines ${ }^{d}$

Technology Transfer Guidelines ${ }^{\text {e }}$

\section{Relevant Market Notice ${ }^{\mathrm{f}}$}

Vertical Guidelines ${ }^{2}$

a Communication from the Commission — Notice — Guidelines on the application of Article 81(3) of the Treaty [2004] OJ C 101/97 (Art 101(3) Guidelines).

${ }^{\mathrm{b}}$ Commission Notice on agreements of minor importance which do not appreciably restrict competition under Article 81(1) of the Treaty establishing the European Community (de minimis) [2001] OJ C 368/13 (De Minimis (2001)); Communication from the Commission Notice on agreements of minor importance which do not appreciably restrict competition under Article 101(1) of the Treaty on the Functioning of the European Union (De Minimis Notice) [2014] OJ C 291/1 (De Minimis (2014)).

c Commission Notice - Guidelines on the effect on trade concept contained in Articles 81 and 82 of the Treaty [2004] OJ C 101/81 (Effect on Trade Concept Guidelines).

d Commission Notice - Guidelines on the applicability of Article 81 of the EC Treaty to horizontal cooperation agreements [2001] OJ 2001/C 3/2 (Horizontal Guidelines (2001)); Communication from the Commission—Guidelines on the applicability of Article 101 of the Treaty on the Functioning of the European Union to horizontal co-operation agreements [2011] OJ C 3/2 (Horizontal Guidelines (2011)).

e Commission Notice - Guidelines on the application of Article 81 of the EC Treaty to technology transfer agreements [2004] OJ C 101/2 (Technology Transfer Guidelines).

${ }^{f}$ Commission Notice on the definition of relevant market for the purposes of Community competition law [1997] OJ C 372/5 (Relevant Market Notice).

g Commission Notice - Guidelines on Vertical Restraints [2000] OJ C 291/1 (Vertical Guidelines(2000)); Commission - Guidelines on Vertical Restraints [2010] OJ C 130/1 (Vertical Guidelines (2010)).

\section{Table 2. References to Competition Soft Law}

\begin{tabular}{|l|l|l|}
\hline Soft Law Instrument & $\begin{array}{l}\text { Decisions Making Reference to the } \\
\text { Instrument }\end{array}$ & References to the Instrument \\
\hline Article 101(3) Guidelines & 16 & 82 \\
\hline De Minimis Notice (2001) & 24 & 28 \\
\hline De Minimis Notice (2014) & 3 & 6 \\
\hline Effect on Trade Concept Guidelines & 19 & 55 \\
\hline Horizontal Guidelines (2001) & 3 & 15 \\
\hline Horizontal Guidelines (2011) & 13 & 31 \\
\hline
\end{tabular}




\begin{tabular}{|l|l|l|}
\hline Technology Transfer Guidelines & 1 & 1 \\
\hline Relevant Market Notice & 6 & 16 \\
\hline Vertical Guidelines (2000) & 4 & 12 \\
\hline Vertical Guidelines (2010) & 5 & 66 \\
\hline
\end{tabular}

Table 3. References with Another Legal Source ${ }^{a}$

\begin{tabular}{|l|l|l|l|l|l|}
\hline & $\begin{array}{l}\text { (European } \\
\text { or BKartA) } \\
\text { Soft Law }\end{array}$ & Commentaries & $\begin{array}{l}\text { Other BKartA or } \\
\text { Commission De- } \\
\text { cisions }\end{array}$ & $\begin{array}{l}\text { (European } \\
\text { or German) } \\
\text { Case Law }\end{array}$ & Hard Law \\
\hline $\begin{array}{l}\text { References in Conjunction } \\
\text { (Total: 60) }\end{array}$ & 14 & 20 & 2 & 27 & 4 \\
\hline $\begin{array}{l}\text { References involving anoth- } \\
\text { er source (Total: 100) }\end{array}$ & 26 & 0 & 12 & 76 & 18 \\
\hline Sum: (Total: 160) & 40 & 20 & 14 & 103 & 22 \\
\hline
\end{tabular}

a Note that the grand total of references involving another legal source identified in Table 3 exceeds the stipulated 160 . This is because several references involved multiple other legal sources.

\section{Annex 1. References per Decision}

\begin{tabular}{|c|c|c|c|c|c|}
\hline Decision File & References & Total & Decision File & References & Total \\
\hline Bo1-165-O1 & 1x Article 101(3), 1x Tech & 2 & В3-129-03 & $2 x$ Trade & 2 \\
\hline B1-116-O4 & $\begin{array}{l}\text { 2x Trade, 2x DM (2001), 6x Article } \\
101(3)\end{array}$ & 10 & В3-134-09 & 1x Horizontal (2011) & 1 \\
\hline $\mathrm{B} 1-248-\mathrm{O} 4$ & 12x Trade & 12 & B3-39-03 & 2x Trade & 2 \\
\hline $\mathrm{B} 1-72-12$ & $\begin{array}{l}\text { 1x DM (2014), 2x Trade, 1x Horizon- } \\
\text { tal (2011) }\end{array}$ & 4 & B3-64-05 & $\begin{array}{l}\text { 1x RM, 1x Trade, 9x Article } \\
\text { 101(3), 2x Vertical }(2000)\end{array}$ & 13 \\
\hline B10-10-10 & 1x DM (2001) & 1 & B3-93-15 & 9x Horizontal (2011) & 9 \\
\hline B10-11-10 & $1 x$ DM (2001) & 1 & B4-1006-o6 & $\begin{array}{l}\text { 13x Horizontal (2001), 4x Article } \\
\text { 101(3), 1x DM (2001), 2x Trade }\end{array}$ & 20 \\
\hline B10-12-10 & $1 x$ DM (2001) & 1 & $\mathrm{~B}_{4}-31-05$ & $\begin{array}{l}\text { 6x RM, 10x Article 101(3), 1x Hori- } \\
\text { zontal (2001) }\end{array}$ & 17 \\
\hline B10-13-10 & 1x DM (2001) & 1 & B4-71-10 & $\begin{array}{l}3 x \text { Article } 101(3), 2 x \text { DM (2014), 2x } \\
\text { Trade, 1x Horizontal (2011) }\end{array}$ & 8 \\
\hline B10-14-10 & 1x DM (2001) & 1 & $\mathrm{~B}_{4}-9-11$ & $\begin{array}{l}5 x \text { Article } 101(3), 2 x \text { DM (2001), 2x } \\
\text { Trade }\end{array}$ & 9 \\
\hline
\end{tabular}




\begin{tabular}{|c|c|c|c|c|c|}
\hline B10-148-05 & $\begin{array}{l}\text { 2x RM, 2x DM (2001), 14x Trade, 7x } \\
\text { Article 101(3), 3x Horizontal (2011) }\end{array}$ & 28 & B6-114-10 & 3x Trade, 9x Article 101(3) & 12 \\
\hline B10-18-10 & 1x DM (2001) & 1 & B6-132-14-2 & 3x DM (2014), 8x Vertical (2010) & 11 \\
\hline B10-19-10 & 1x DM (2001) & 1 & B6-22-16 & 3x RM & 3 \\
\hline B10-20-10 & 1x DM (2001) & 1 & B6-32-15 & 1x Trade, 3x Article 101(3) & 4 \\
\hline B10-21-10 & 1x DM (2001) & 1 & B6-94-10 & $\begin{array}{l}\text { 6x Horizontal (2011), 7x Article } \\
101(3)\end{array}$ & 13 \\
\hline B10-22-10 & 1x DM (2001) & 1 & B7-17-06 & 1x Horizontal (2001) & 1 \\
\hline B10-23-10 & $1 x$ DM (2001) & 1 & B7-22-07 & 1x DM (2001), 1x Horizontal (2011) & 2 \\
\hline B10-24-10 & 1x DM (2001) & 1 & B7-26-17 & 3x Trade, $1 x$ Horizontal (2011) & 4 \\
\hline B10-25-10 & 1x DM (2001) & 1 & B7-30-07-1 & $\begin{array}{l}7 x \text { Article } 101(3), 1 x \text { Horizontal } \\
(2011)\end{array}$ & 8 \\
\hline B10-44-09 & 1x DM (2001) & 1 & B7-46-13 & $\begin{array}{l}7 x \text { Article } 101(3), 2 x \text { Horizontal } \\
(2011)\end{array}$ & 9 \\
\hline B10-45-09 & 1x DM (2001) & 1 & B8-113-03-1 & 2x Trade, $2 x$ Vertical (2000) & 4 \\
\hline B10-47-09 & 1x DM (2001) & 1 & B9-121-13 & $\begin{array}{l}\text { 1x DM (2001), 4x Vertical (2010), 1x } \\
\text { Article 101(3) }\end{array}$ & 6 \\
\hline B10-48-09 & 1x DM (2001) & 1 & B9-128-12 & 1x Trade & 1 \\
\hline B2-58-09 & 1x RM & 1 & B9-136-13 & 1x Trade & 1 \\
\hline B2-98-11 & $\begin{array}{l}\text { 2x DM (2001), 1x Trade,35x Vertical } \\
(2010), 3 x \text { Article 101 }(3)\end{array}$ & 41 & B9-149-04 & 1x Vertical (2000) & 1 \\
\hline B3-11-13-1 & 1x Horizontal (2011) & 1 & B9-188-05 & 1x Trade & 1 \\
\hline B3-11-13-2 & 1x Horizontal (2011) & 1 & B9-55-03 & 1x Trade & 1 \\
\hline В3-123-08 & 5x Vertical (2000), 1x Vertical (2010) & 6 & B9-66-10 & $\begin{array}{l}\text { 3x RM, 18x Vertical (2010), 3x Hor- } \\
\text { izontal (2011), 1x Article 101(3) }\end{array}$ & 24 \\
\hline
\end{tabular}

